\author{
Agnieszka Janik \\ Uniwersytet Wrocławski \\ agnieszkaanna.janik@gmail.com
}

\title{
Warunki do zabawy na Przygodowym Placu Zabaw w Berkeley Marina w Kalifornii
}

\section{Summary \\ Play conditions at the City of Berkeley's Marina Adventure Playground}

The following publication is an attempt to describe observed reality, especially in terms of conditions provided for play. This article is the result of author's research visit at the City of Berkeley's Marina Adventure Playground. During the visit the author had the opportunity to attend the unique and dynamic play environment of adventure playground in Berkeley Marina that enables its users to saw, hammer, build forts, play with water and fire. At the same time the it was designed in the way that encourages to play not only children's but also adults. The presented content includes: the concept of playground in Berkley, its the design of space and play equipment, its policy and role of play leaders. The research methodology included qualitative procedure. Qualitative analysis, ethnographic observation and qualitative research interview has been used.

Słowa kluczowe: przygodowe place zabaw, zabawa na zewnątrz, współczesna zabawa, deprywacja zabawy

Keywords: adventure playground, outdoor play, contemporary play, play deprivation

\section{Wprowadzenie}

Dziecięca zabawa była przez lata marginalizowana bądź pomijana w dyskursie społecznym i medialnym, podobnie jak kategorie „dziecko” i „dzieciństwo”. Dzieci uważano za „miniatury dorosłych” i istoty dopiero „stające się” (Postman 1982: 14). Z początkiem XIX wieku społeczna wizja dziecka uległa przeobrażeniom - dzieci uznano za istoty ,już będące"; zaczęto je postrzegać jako pełnoprawnych aktorów życia społecznego zdolnych do podejmowania znaczących decyzji (zob. Corsaro 1997; Prout 2005; James, James 2004). Wraz ze zmianą społecznego wizerunku dziecka również rola i znaczenie i zabawy uległy przeobrażeniom. Obecnie kwestie dziecięcej zabawy podejmowane są przez środowiska badaczy, społeczników i rodziców z całego świata (Brown, Patte 2013: 6). Międzynarodowym dokumentem gwarantującym dzieciom prawo do zabawy jest Konwencja o prawach dziecka ratyfikowana w 1989 roku przez większość państw świata. Okazuje się jednak, że warunki i możliwości dziecięcej zabawy są bardzo zróżnicowanie, niejednoznaczne i relatywne (Sutton-Smith 1997: 296). W prowadzonych debatach ważnym zagadnieniem jest swobodna 
zabawa dzieci na świeżym powietrzu bez nadzoru rodziców (Brown, Patte 2013: 86-84). Wielu badaczy stwierdziło, że taki rodzaj zabawy stanowi znikomą część codziennych zajęć i aktywności dzieci. Tym samym dzieci coraz rzadziej mają okazję do poznawania i odkrywania najbliższego otoczenia $\mathrm{w}$ gronie rówieśniczym. Zjawisko to określono mianem deprywacji zabawy, a do jego głównych przyczyn zaliczono: zbyt długi czas spędzany przez dzieci w szkole oraz przed ekranami komputerów, telewizorów i urządzeń typu smart, brak bliskich relacji dzieci z naturą (zob. Louv 2014; Wilson 2012), nadopiekuńcze postawy rodziców oraz nieatrakcyjność placów zabaw i zewnętrznych przestrzeni zabaw (zob. Brown, Patte 2013; Hughes 1996; Frost 2006; Shackell i in. 2008).

Interesującą i wartościową alternatywę w projektowaniu zewnętrznych przestrzeni zabaw stanowią przygodowe place zabaw. Ich tradycja obejmuje kontakt $\mathrm{z}$ wiatrem, wodą, powietrzem i ziemią (Frost 1988; Hughes 1996; Eriksen 1985). Za autora koncepcji przygodowych placów zabaw uważa się Carla Theodora Sørensena - duńskiego architekta krajobrazu. Sørensen w opublikowanej w 1931 roku książce „Parker og Parkpolitik” („Parki i Regulacje dotyczące Parków”) po raz pierwszy przedstawił idee, które później złożyły się na koncepcję przygodowych obiektów. Użyte przez niego sformułowanie ,,skrammellegeplads" nawiązywało do stworzenia „śmieciowego" miejsca dla dzieci (Brett, Moore, Provenzo 1993). Zwięzłego opisu koncepcji tego typu obiektów dostarcza broszura wydana w 1973 roku przez National Playing Fields Association (Krajowe Stowarzyszanie Placów Zabaw w Londynie):

Przygodowy plac zabaw jest miejscem, gdzie dzieci w każdym wieku, pod przyjaznym nadzorem, mogą podejmować się rzeczy, które trudno jest im robić w zatłoczonym, miejskim społeczeństwie; są to aktywności, takie jak: budowanie szałasów, ścian, fortów, kryjówek, domków na drzewie; rozpalanie ognia i gotowanie, wspinanie się na drzewa, kopanie, rozbijanie kempingów; być może dbanie o ogród i hodowanie zwierząt; jak również bawienie się w gry zespołowe, gry grupowe, malowanie, przebieranie się, lepienie i modelowanie lub robienie niczego.

Koncepcja przygodowych placów zabaw zakłada zabawę dzieci na świeżym powietrzu bez nadzoru dorosłych. Nadzór został zastąpiony przyjaznym wsparciem zapewnianym przez liderów zabawy (ang. play leaders). Pojęcie „lider zabawy” najczęściej oznacza zawód wykonywany przez osoby towarzyszące dzieciom podczas zabawy na przygodowych placach zabaw ${ }^{1}$. Współcześnie w Europie funkcjonuje około 1000 obiektów tego typu. Najwięcej zlokalizowanych jest w Dani, Szwecji, Francji, Niemczech, Anglii i Holandii. Wiele znajduje się także w Japonii ${ }^{2}$.

Niniejszy artykuł został poświęcony charakterystyce Przygodowego Placu zabaw w Berkeley Marina w Kalifornii ${ }^{3}$. Celem artykułu jest zapoznanie czytelnika z warunkami do zabawy, jakie stworzono dzieciom na tym placu. W Polsce przygodowe place zabaw

\footnotetext{
http://www.allianceforchildhood.org/playwork, 29.11.2015.

http://www.adventureplay.org.uk, 29.10.2015.

Oryginalna nazwa placu zabaw: the City of Berkeley's Marina Adventure Playground.
} 
nie zostały rozpoznane przez środowisko pedagogiczne. Tym samym niniejszy artykuł może stanowić jeden z punktów wyjścia do pobudzenia dyskusji nad różnorodnością przestrzeni współczesnych placów zabaw w gronie polskich praktyków i teoretyków zabawy.

\section{Metodologiczne podstawy badań}

Artykuł zawiera analizę materiałów zgromadzonych i opracowanych przez autorkę podczas dwutygodniowej wizyty badawczej na terenie Przygodowego Placu Zabaw w Berkeley Marina w Kalifornii ${ }^{4}$. Badania były prowadzone na przełomie sierpnia i września 2015 roku. Ich celem było zrozumienie i poznanie warunków do zabawy stworzonych na placu przy uwzględnieniu jego specyfiki. Tym samym w niniejszym artykule podęto próbę udzielenia odpowiedzi na główny problem badawczy:

Jakie są warunki do zabawy na terenie Przygodowego Placu Zabaw w Berkeley Marina w Kalifornii?

Aby udzielić odpowiedzi na postawiony problem badawczy należało zastanowić się, jakie czynniki oddziałują na zabawę dzieci. Na podstawie studiów literatury przedmiotu sformułowano następujące szczegółowe problemy badawcze:

- Jaka jest koncepcja funkcjonowania placu?

- Jak została zorganizowana przestrzeń placu?

- Co znajduje się na terenie placu?

- W jaki sposób liderzy zabawy organizują warunki do zabawy na terenie placu?

Ze względu na jakościową specyfikę problemów badawczych badania zostały osadzone w paradygmacie interpretatywnym (Denzin, Lincoln 2009). Wiodącą metodą gromadzenia danych była obserwacja uczestnicząca o charakterze etnograficznym. Badania etnograficzne mają na celu dostarczenie wiarygodnej charakterystyki i opisu życia badanych. Badania tego typu należy prowadzić w naturalnym środowisku funkcjonowania badanej zbiorowości, dzięki czemu jej zachowanie w większej mierze będzie pozbawione zażenowania i skrępowania (Kawecki 1994: 46). Obserwacja została uzupełniona jakościowymi wywiadami z pięcioma liderami zabawy i z koordynatorką placu. Wywiady zostały przeprowadzone na podstawie przewodnika do jakościowych wywiadów badawczych i skoncentrowane wokół następujących zagadnień: filozofia i historia placu, zadania liderów zabawy, motywacje wyboru placu jako miejsca pracy, zasady użytkowania placu, bezpieczeństwo, relacje między rodzicami i dziećmi, koncepcja zabawy. Obserwacji uczestniczącej towarzyszyły także swobodne rozmowy z rodzicami i dziećmi bawiącymi się w obiekcie na temat ich odczuć, gromadzonych doświadczeń i zdobywanych umiejętności. Ponadto badania zostały uzupełnione jakościową analizą dokumentów i wytworów oraz analizą materiałów wizualnych. Badania naznaczone były dużą subiektywnością wynikającą z obranej strategii badawczej i indywidualnej interpretacji zjawisk obserwowanych przez autorkę w czasie wizyty badawczej.

4 Wizyta stanowiła integralną część projektu badawczego finansowanego w ramach Konkursu Wewnętrznego Wydziału Nauk Historycznych i Pedagogicznych Uniwersytetu Wrocławskiego w 2015 roku. 
W trakcie badań został zebrany obszerny materiał, na który składały się między innymi notatki z obserwacji uczestniczącej, transkrypcje wywiadów, notatki z rozmów z rodzicami i dziećmi, wytwory zastane: regulamin obiektu, dokumenty dotyczące powstania obiektu i jego funkcjonowania, artykuły z prasy codziennej, raporty związane z zarządzaniem ryzykiem i bezpieczeństwem, informacje na temat wypadków, informacje przekazywane rodzicom i opiekunom, ulotki i broszury informacyjne, źródła wizualne: zdjęcia, kroniki, informacje zamieszczone na stornie internetowej. Przeprowadzone jakościowe wywiady badawcze z liderami zabawy trwały około czterdziestu pięciu minut, a z koordynatorką placu dwie godziny. Rozmowy odbywały się na placu zabaw oraz w pobliskim Centrum Natury Shorebird, co sprzyjało refleksji rozmówców nad ich aktualnymi zadaniami i bieżącymi wydarzeniami.

W wyniku analizy materiałów badawczych zostały wyłonione znaczące kategorie, które umożliwiły opisanie warunków do zabawy stworzonych na placu. Analiza miała charakter ciągły, co oznacza, że wstępne kategorie wyłonione na podstawie studiów literatury przedmiotu ulegały wielokrotnym modyfikacjom. Ostatecznie za znaczące kategorie uznano kontekst i okoliczności założenia placu, ogólne regulacje dotyczące funkcjonowania placu, specyfikę koncepcji placu, zasady użytkowania placu, organizację przestrzeni, rolę i zadania liderów zabawy. Ze względu na ograniczoną objętość artykułu w dalszej części zostały scharakteryzowane trzy wiodące kategorie w dużej mierze warunkujące zabawę w omawianym obiekcie, a mianowicie: koncepcja placu, organizacja przestrzeni placu i jego wyposażenie oraz rola i zadania liderów zabawy w kontekście organizowania warunków do zabawy. Poniżej znajduje się charakterystyka tych elementów.

\section{Warunki do zabawy na przykładzie Przygodowego Placu Zabaw w Berkeley Marina}

\section{Specyfika koncepcji placu}

Przygodowy Plac Zabaw w Berkeley Marina powstał w 1979 roku w odpowiedzi na inicjatywę zakładania przygodowych placów zabaw promowaną przez Adventure Playground Association in America (APAiA, Stowarzyszenie Przygodowych Placów Zabaw w Ameryce). W okresie letnim otwarty jest przez cały tydzień. W tym czasie wsparcie dzieciom zapewnia pięciu liderów zabawy. W okresie roku szkolnego obiekt działa jedynie w weekendy i pracuje w nim czwórka liderów.

Koncepcja placu w Berkeley Marina w dużej mierze została opracowana na podstawie przewodnika zakładania przygodowych placów zabaw opracowanego przez APAiA. Głównym celem działalności obiektu jest zapewnienie dzieciom warunków do swobodnej zabawy na świeżym powietrzu oraz wyposażenie ich w tak zwane „umiejętności przetrwania". Do umiejętności tych należą: wspinanie się, budowanie fortów, piłowanie drewna, wbijanie gwoździ, malowanie, kopanie w ziemi, budowanie szałasów, ale także współpraca pomiędzy dziećmi i rodzicami, sprawna komunikacja i wzajemna pomoc. Koncepcja zabawy na placu w większości jest spójna z ogólnymi założeniami budowania tego typu 
obiektów. Znamienną różnicę stanowi otwartość placu w Berkeley Marina na obecność i aktywne uczestnictwo dorosłych. Oznacza to, że podczas gdy jednym z podstawowych założeń tworzenia przygodowych placów zabaw jest zapewnienie dzieciom przestrzeni wolnej od dorosłych (wyłączywszy liderów zabawy), to na placu w Berkeley razem z dziećmi bawią się ich opiekunowie. Ponadto wszystkie dzieci przebywające w obiekcie powinny znajdować się pod nieustanną i aktywną obserwacją dorosłych, a dzieci poniżej siedmiu lat powinny znajdować się w zasięgu ręki opiekuna.

Zabawa na przygodowym placu wymaga wykorzystania narzędzi i farb, które można uzyskać po odnalezieniu i przyniesieniu do liderów zabawy: 1) dziesięciu gwoździ, 2) pięciu kawałków połamanego bądź rozwarstwionego drewna, 3) pięciu sztuk śmieci bądź 4) jednego „Mr Dangerous” („Pana Niebezpiecznego”), czyli kawałka deski z wystającym gwoździem. Liderzy zabawy, na prośbę dzieci i dorosłych, udostępniają „wyszukiwacze gwoździ”, czyli przyczepione do kijków sznurki z zawiązanymi na końcach magnesami. Odnalezienie gwoździ i pozostałych elementów nie jest trudne, gdyż liderzy, burząc drewniane konstrukcje, często pozostawiają gwoździe w piachu.

\section{Organizacja przestrzeni placu i jego wyposażenie}

Plac jest zlokalizowany w Marinie, w Parku Shorebird położonym w południowo-wschodniej części miasta Berkeley nad zatoką San Francisco (fot. 1.). Obiekt jest ogrodzony drewnianym płotem, a na jego teren prowadzi główna brama (fot. 2) oraz wejście boczne. Przy głównej bramie znajduje się największe stanowisko pracowników wraz z magazynem urządzeń budowlanych. Jest to miejsce, w którym liderzy zabawy udzielają informacji oraz wydają narzędzia. Na obrzeżach placu można odnaleźć inne specjalnie oznaczone miejsca tego typu, gdzie pobiera się drewno i deski. Po uzyskaniu dotacji w 2015 roku na placu umieszczono pianino. Inny muzyczno-sensoryczny element jego wyposażenia stanowi struktura wykonana z materiałów o zróżnicowanych fakturach oraz urządzeń wydających odmienne dźwięki, takich jak bębny i struny. W północnej części obiektu można odnaleźć przede wszystkim drewniane struktury pokryte wieloma warstwami kolorowej farby, swoim wyglądem przypominające duże i małe domki, szałasy, forty oraz konstrukcje wykonane ze sznurów. Te pojedyncze, jak i połączone w większe kompleksy struktury wybudowane zostały obok siebie - „tam, gdzie było miejsce”. W południowej części nie jest tak tłoczno. Znajdują się w niej dwie większe drewniane fortyfikacje i kilka mniejszych, dwie stare łodzie i odgrodzona krzakami kolejka linowa. Budowle czasami zawierają prowizoryczne drzwi, półki i hamaki wykonane z materiałów przybitych do desek oraz stare materace i pudła często służące za siedziska. Fortyfikacje mają zazwyczaj kilka poziomów. $\mathrm{Na}$ wyższe piętra można wejść po schodach, drabinie bądź wspiąć się po linach. Teren przy wejściu po stronie północno-zachodniej został wyposażony w ławy i stoły ułatwiające prace konstruktorskie, takie jak zbijanie desek, piłowanie, wyciągnie gwoździ. Naprzeciwko zlokalizowano zieloną strefę przeznaczoną do czynności ogrodniczych. W północnej części umieszczono dużej wielkości „pajęczą sieć” wspinaczkową wykonaną z grubych sznurów i połączoną z innymi systemami linowych konstrukcji (fot. 3). 


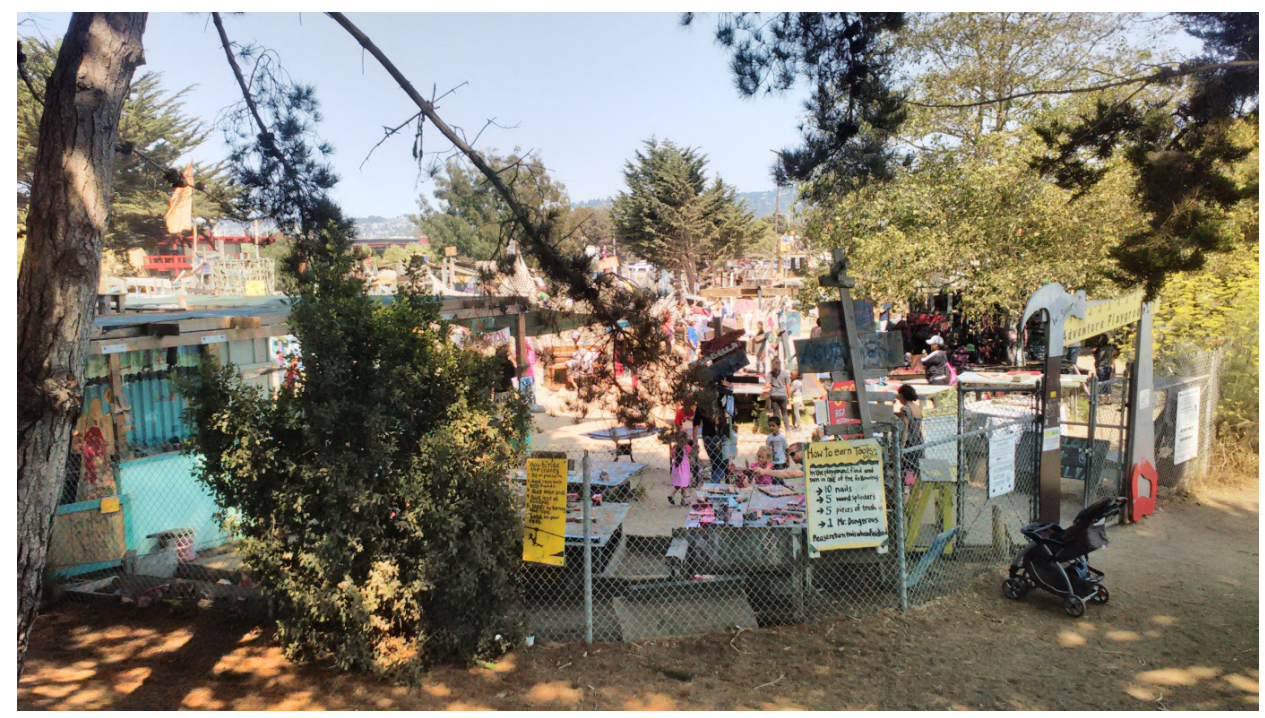

Fot. 1. Widok na Przygodowy Plac Zabaw w Berkeley Marina z Parku Shorebird Źródło: zdjęcie wykonane przez autorkę.

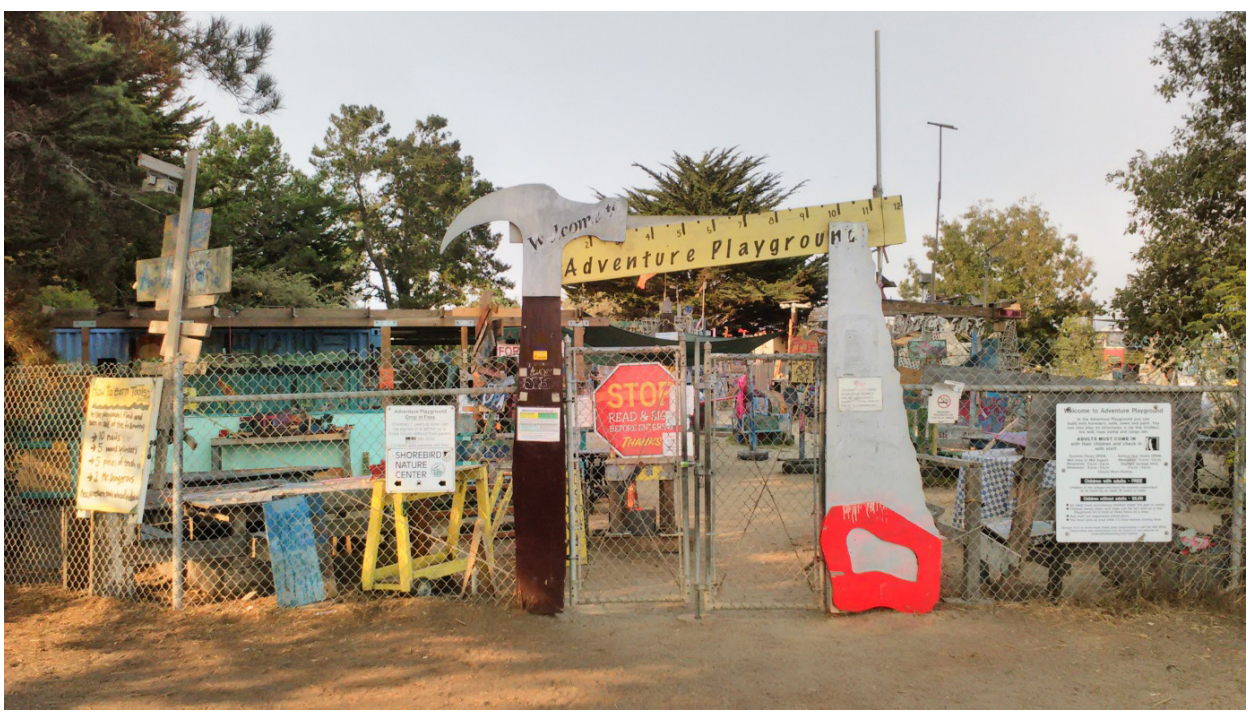

Fot. 2. Główna brama wejściowa na plac

Źródło: zdjęcie wykonane przez autorkę. 


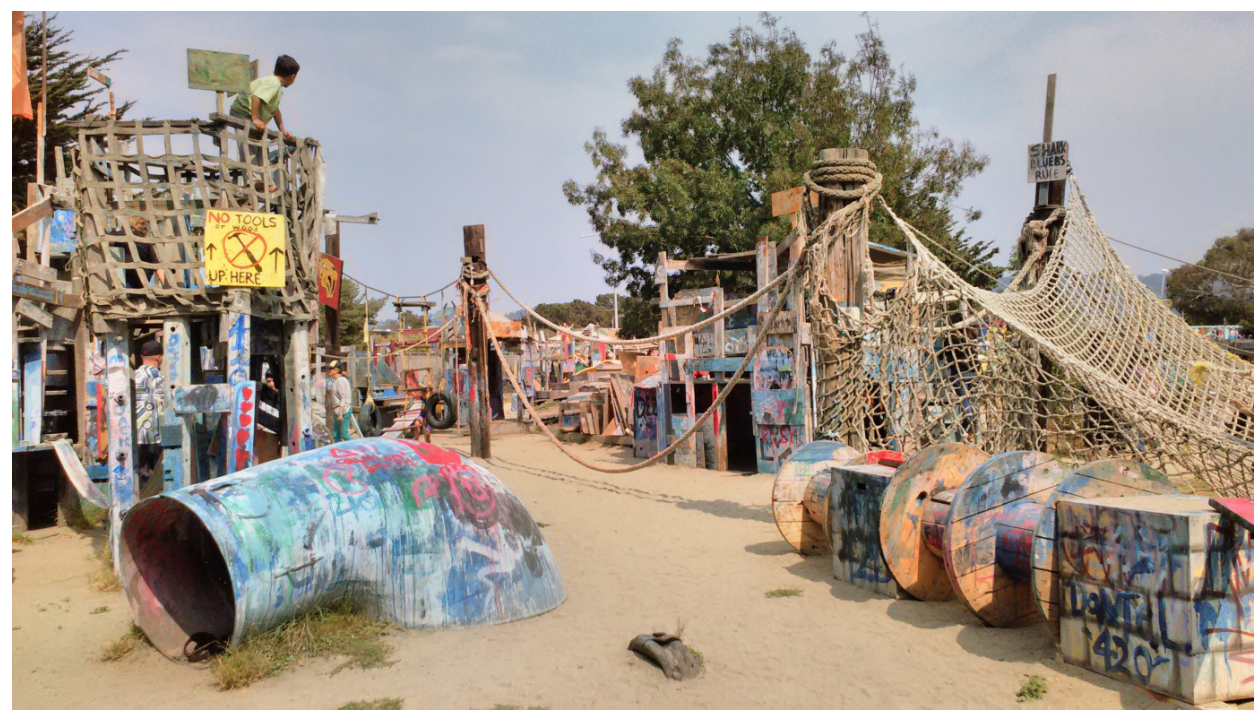

Fot. 3. Widok na północną część placu. Po prawej stronie znajduje się najbardziej rozbudowana konstrukcja linowa

Źródło: zdjęcie wykonane przez autorkę.

W południowo-wschodniej części znajduje się niewielkie wzgórze. Nieopodal niego leżą rury wykonane z grubego plastiku bądź starych opon często wykorzystywane do sturlania się ze wzniesienia. W południowo-zachodniej części zlokalizowano kolejkę linową potocznie nazywaną tyrolką. Na placu rośnie kilka drzew zapewniających bawiącym się cień. Jego nawierzchnię stanowią naturalnie występujące piasek, trawa i krzaki. Całość placu sprawia wrażenie miejsca magicznego, niepasującego do otaczającej go przestrzeni.

\section{Rola i zadania liderów zabawy w kontekście organizowania warunków do zabawy}

Odpowiednie warunki do zabawy zapewniają pracownicy obiektu. Od lidera zabawy wymaga się określonych kompetencji oraz umiejętności społecznych umożliwiających mu efektywne realizowanie zadań w specyficznym i dynamicznym środowisku pracy. Liderzy powinni unikać dyrektywnego prowadzenia dzieci i ingerowania w ich zabawę tym samym przyzwalając na swobodę i dowolność ich działań z jednoczesnym zadbaniem o bezpieczeństwo. Do najczęstszych fizycznych czynności wykonywanych przez liderów zabawy należą: przerzucanie łopatą piachu przy konstrukcji kolejki linowej, usuwanie przeszkód i zebranie przedmiotów stwarzających niebezpieczeństwo. Pracownicy są także zobowiązani do ciągłego monitorowania stabilności powstających budowli oraz rozbierania tych, które mogą stwarzać zagrożenie, na przykład niestabilnych, posiadających płaski dach czy luźno przymocowane elementy.

Praca na placu jest angażująca, dynamiczna i w zasadzie nieustająca, dlatego też istotnym elementem pracy liderów jest uświadomienie ich o konieczności i istotności wykony- 
wania drobnych czynności porządkowych, takich jak grabienie piasku i zbieranie desek. Ważnym elementem pracy liderów jest także nawiązanie współpracy z opiekunami dzieci, zaangażowanie ich do pomocy w utrzymaniu porządku na trenie placu oraz zachęcenie do wchodzenia $\mathrm{w}$ interakcje $\mathrm{z}$ dziećmi i podejmowania z nimi wspólnej zabawy.

Warto także zauważyć, że liderzy pracujący na placu w Berkeley Marina nie znaleźli się tam przypadkowo. Część z nich zaczęła swoją pracę jako wolontariusze, inni wychowywali się na przygodowych placach zabaw, które aktualnie nie istnieją.

\section{Wnioski - na czym polega „przygodowa” zabawa?}

Zabawa na Przygodowym Placu Zabaw w Berkeley Marina przyjmuje specyficzną postać. W nawiązaniu do przeprowadzonych analiz można wskazać na jej charakterystyczne cechy. I tak „przygodowa” zabawa:

- w dużej mierze polega na czynnościach budowlanych i manipulacyjnych, wspinaniu się po konstrukcjach linowych i drabinach, przemieszczaniu się po niestabilnych i nietrwałych powierzchniach, czyli przebywaniu w szybko zmieniającym się środowisku zawierającym elementy ryzyka i stanowiącym dla dziecka wyzwanie,

- ma dynamiczny charakter i jest kierowana własną aktywnością dziecka,

- polega na uczeniu się przez doświadczenie (zob. Dewey 2005), podejmowaniu samodzielnych decyzji, testowaniu własnych granic i możliwości, eksplorowaniu, doświadczaniu i odkrywaniu otoczenia w towarzystwie rówieśników i rodziców,

- odbywa się w przestrzeni oswojonej przez dziecko, która staje się dla niego miejscem (zob. Tuan 1987: 13). Plac stwarza dzieciom możliwości do naznaczania przestrzeni oraz kreowania przestrzeni intymnej stanowiącej „otwarte przeżywanie” chronione przed wzrokiem i kontrolą dorosłych (zob. Nalaskowski 2002: 63),

- wiąże się rozwijaniem myślenia przyczynowo-skutkowego, wytrwałości, twórczości i kreatywności; często polega na zaplanowaniu projektu budowy, jego wielkości i czasu realizacji, przygotowaniu potrzebnych materiałów i sprzętów, a także na modyfikacji pierwotnego planu i wdrożeniu poprawek,

- uczy współodpowiedzialności za środowisko życia i zabawy. Dzieci nadają własne znaczenia rzeczywistości i aktywnie na nią oddziałują. Tym samym budują poczucie przynależności i odpowiedzialności za miejsce, w którym przebywają,

- umożliwia swobodne nawiązywanie kontaktów, współpracę z rodzicami i rówieśnikami, kształtuje umiejętności komunikacyjne.

Zabawa na placu w Berkeley Marina jest zjawiskiem złożonym i wielowymiarowym. Ponadto rzeczywistość placu nasycona jest różnorodnością kolorów i dźwięków, takich jak odgłosy wbijania gwoździ, piłowania drewna, nawoływania rodziców, śmiechy i krzyki, wyrazy ekscytacji. 


\section{Podsumowanie}

Artykuł stanowił próbę rekonstrukcji subiektywnego wglądu autorki w dynamiczną rzeczywistość Przygodowego Placu Zabaw w Berkeley Marina oraz próbę uchwycenia jego wielowymiarowości w kontekście stworzonych na nim warunków do zabawy.

Należy podkreślić, że plac w Berkeley Marina, podobnie jak inne obiekty tego typu, sprzyja odkrywczej aktywności dzieci, oddziałuje na ich rozwój społeczny, fizyczny, psychomotoryczny i emocjonalny. Plac umożliwia dzieciom swobodne działania w świecie, w którym ich wolność jest w wielu wymiarach ograniczana oraz stwarza im przestrzeń do gromadzenia takich doświadczeń, które trudno jest zdobyć w szkole, domu i dorastając w środowisku miejskim.

\section{Literatura}

Brett A., Moore R.C., Provenzo E.F. (1993), The complete playground book. New York, Syracuse University Press.

Brown F., Patte M. (2013), Rethinking Children's Play. London, Bloomsbury.

Corsaro W.A. (1997), The sociology of Childhood. California, Sage Publication.

Denzin N.K., Lincoln Y.S. (2009), Wprowadzenie. Dziedzina i praktyka badań jakościowych, W: N.K. Denzin, Y.S. Lincoln (red.), Metody badań jakościowych, tom 1. Warszawa, Wydawnictwo Naukowe PWN.

Dewey J. (2005), Moje pedagogiczne credo. Warszawa. Wydawnictwo Akademickie „Żak”.

Eriksen, A. (1985), Playground Design: Outdoor Environments for Learning and Development. New York, Van Nostrand Reinhold Company.

Frost J.L. (1988), Evolution of American Playgrounds. "Young Children" 43(5), http://www.leginfo. ca.gov/.const/.article_13A, 11.11.2015.

Frost J.L. (2006), The dissolution of children's outdoor play: Causes and consequences. Prezentacja podczas forum: The Value of Play: A Forum on Risk, Recreation and Children's Health, http:// cgood.org/assets/attachments/Frost_-_Common_Good___FINAL.pdf, 2.02.2015.

Hughes B. (1996), Play environments: A question of quality. London, PLAYLINK.

James A., James A., L. (2004), Constructing Childhood. Theory, Policy and Social Practice. England, Palgrave Macmillan.

Kawecki I. (1994), Metoda etnograficzna w badaniach edukacyjnych. Łódź, Wydawnictwo Państwowej Wyższej Szkoły Sztuk Pięknych.

Konwencja o Prawach Dziecka przyjęta przez Zgromadzenie Ogólne Narodów Zjednoczonych dn. 20 listopada $1989 \mathrm{r}$.

Louv R. (2014), Ostatnie dziecko lasu. Jak uchronić nasze dzieci przed zespołem deficytu natury. Warszawa, Wydawnictwo Relacja.

Nalaskowski A. (2002), Przestrzenie i miejsca szkoły. Warszawa, Wydawnictwo Impuls.

National Playing Fields Association (1973), What is an Adventure Playground. London, National Playing Fields Association, https://archive.org/details/WhatIsAnAdventurePlayground, 10.09.2015

Postman N. (1982), The Disappearance of Childhood. New York, Delacorte Press. 
Prout A. (2005), The Future of Childhood: Towards the Interdisciplinary Study of Children. London, Falmer Press.

Shackell A. i in. (2008), Design for play: A guide to creating successful play spaces. London, Play England, http://www.playengland.org.uk/resources/design-for-play.aspx, 10.09.2015.

Sutton-Smith B. (1997), The ambiguity of Play. Cambridge, Harvard University Press.

Tuan Y-F. (1987), Przestrzeń i miejsce. Warszawa, Państwowy Instytut Wydawniczy.

Vance B. (1976), A Guide to the Development of the Adventure Playground. America, Adventure Playground Association in America.

Wilson R. (2012), Nature and Young Children. Encouraging creative play and learning in natural environments. London, New York, Routledge.

\section{Netografia}

www.allianceforchildhood.org/playwork, 29.11.2015. www.adventureplay.org.uk/history2.htm, 10.11.2015. 